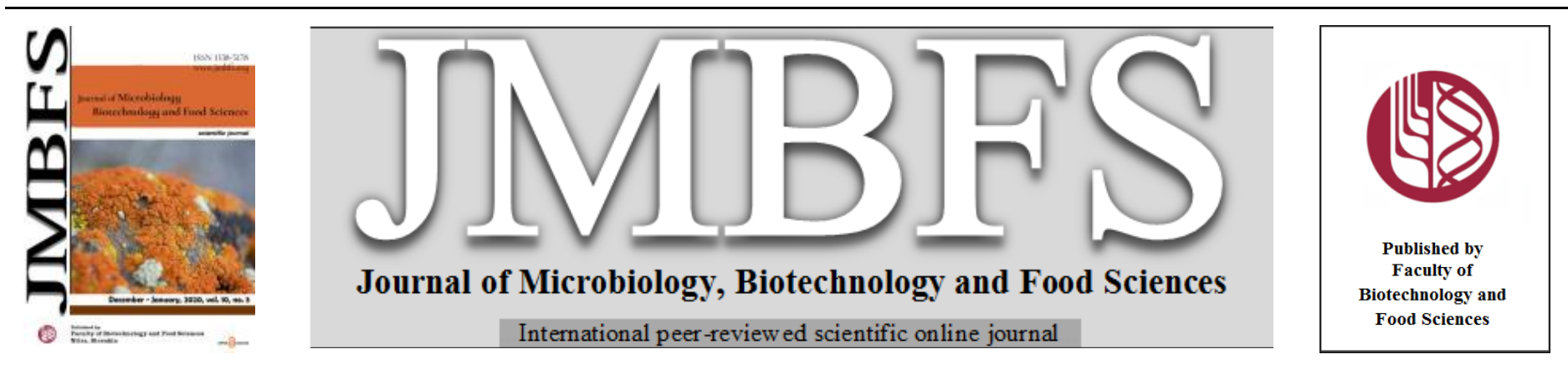

\title{
GARLIC-GINGER AS POTENTIAL BIO-PRESERVATIVE IN FERMENTED MAIZE AND SORGHUM PASTES
}

\author{
Abiola Folakemi Olaniran ${ }^{1,2}$ *, Sumbo Henrietta Abiose ${ }^{3,}$ and Adeniran Adekanmi Hezekiah ${ }^{3}$ \\ Address(es): Abiola Folakemi Olaniran, \\ *1 Landmark University, College of Pure and Applied Sciences, Department of Microbiology, 251101, Omu-Aran, Kwara State, +2348034961968 : \\ ${ }^{2}$ Landmark University, College of Agricultural Sciences, Department of Food Science and Nutrition, 251101, Omu-Aran. \\ ${ }^{3}$ Obafemi Awolowo University, Faculty of Technology, Department of Food Science and Technology, 220282, Ile-Ife, Osun State.
}

*Corresponding author: olaniran.abiola@lmu.edu.ng

doi: 10.15414/jmbfs.2020.10.3.467-473

\section{ARTICLE INFO}

Received 24. 6. 2019

Revised 14. 8. 2020

Accepted 24. 9. 2020

Published 1. 12. 2020

Regular article

open $\partial_{\text {ACCESS }}$

\begin{abstract}
Garlic and ginger are natural spices with potentials as biopreservatives and allied health benefits. Fermented pastes either from maize or sorghum have a shelf life of fewer than 10 days except when refrigerated. In this study, garlic and ginger were added separately and in combinations to the fermented pastes prepared from maize and sorghum grains with a view to extending its shelf life resulted in 7 treatments. During storage for 4 weeks at ambient and refrigeration temperatures, the microbial load was enumerated and isolates identified using conventional methods. Physicochemical properties and shelf-life of the paste were also evaluated. Prominent in the fermented pastes during storage were 8 species of lactic acid bacteria and yeast (Saccharomyces cerevisiae and Saccharomyces rouxii). Garlic inhibited the growth of Candida utilis, Candida mycoderma, Candida tropicalis, Candida krusei, and Rhodotorula glutinis in paste during storage. Bio-preserved paste using $4 \%$ garlic with $2 \%$ ginger had the best preservative effect on total viable counts (8.29$11.30 \mathrm{CFU} / \mathrm{g})$, lactic acid bacteria (8.3-9.70 CFU/g) and yeast (4.69-9.45 CFU/g) counts. The study established that fermented pastes produced from either maize or sorghum can be effectively bio preserved using garlic, ginger, and garlic-ginger at 2 or $4 \%$ for 4 weeks without spoilage at ambient temperature $\left(27 \pm 2^{\circ} \mathrm{C}\right)$; thus, extending its shelf life.
\end{abstract}

Keywords: Fermented paste, Biopreservatives, Garlic, Ginger, Maize, Sorghum, Shelf life

\section{INTRODUCTION}

Quality protein maize (QPM) varieties are being encouraged in developing countries with maize as major constituents of their diets compared to the conventional maize (Gunaratna, et al., 2019). Different varieties are used for the production of several traditional foods especially in Africa such as ogi, The main diets of poor people are cereals with scanty protein sources like eggs and meat (Oluwakemi and Omodele, 2015). Quality Protein Maize (QPM) has a biological protein value of $80 \%$ compared with conventional maize $(45 \%)$ Besides, It has more lysine (30\%), tryptophan (55\%) and less leucine (38\%) with the potential in alleviating protein malnutrition (Maseta et al., 2017). The superiority of nutritional assessment on consumption of quality protein maize by human being above other varieties has been demonstrated (Tandzi et al., 2017). Sorghum is the world's fifth cereals food crop. A good source of starch and protein, its gluten-free serves as an alternative for gluten intolerance people (Kulamarva et al., 2009). Fermentation is a traditional, age-old technique of transforming grains generally, into diverse forms of food that constitute the daily diets of most African populations. This processing technique has been well documented to improve shelf life, nutrient bioavailability and health benefits (Olaniran and Abiose, 2019). Some of the locally fermented products are fura, $o g i$ and tings. Most of these fermented products especially $o g i$ has relatively shor shelf life of 10 days at room temperature depending on the moisture content and microorganisms present (Olaniran et al., 2019). Refrigeration is a viable option when the power supply is regular for preservation if the family can afford the bill. Therefore there is a need to extend their shelf life to enhance its availability on the shelf and reduce the rigor of frequent production in small batches. Biopreservation is important in the food industry. Ginger powder compared well with potassium sorbate, citric acid, and sodium metabisulphite (Singh, 2018) Also, Olaniran et al. (2015) reported that garlic possesses antimicrobial activities in food. Garlic and ginger satisfy the questions of safety and generally regarded as safe (GRAS) (Olaniran et al., 2020). They are indispensable in the preparation of daily food and reported to possess compounds with various benefits (Tattari et al., 2013). Garlic and ginger are gaining increasing interest because of relatively safe status, acceptance by consumers, and a potential alternative to chemical preservatives (Nath et al., 2014). Hence, the study was designed in view of extending the shelf life of fermented pastes produced from maize and sorghum with garlic and ginger as biopreservative at ambient and refrigeration temperatures.

\section{MATERIAL AND METHODS}

\section{Preparation of powder garlic and ginger}

Garlic and ginger powder was prepared according to Olaniran et al. (2015) from fresh garlic bulbs and ginger rhizomes. Four hundred (400) gram of fresh garlic bulbs and ginger rhizomes were cleaned, peeled and dried in hot air oven (Gallenkamp, UK) at $65^{\circ} \mathrm{C}$ for $12 \mathrm{~h}$. Dried samples were pulverized with a grinder (Marlex Appliances PVT, India). The garlic and ginger powdered samples were then sieved in a mesh $(50 \mu \mathrm{m})$.

\section{Production of biopreserved ogi paste}

The paste produced from clean sorghum (red variety) and quality protein maize grains from the Institute of Agricultural Research and Training (I.A.R.T.) Ibadan, Nigeria. The grains soaked in clean water for $72 \mathrm{~h}$ individually, drained, wetly milled to smooth paste in attrition mill using Thomas Wiley Model ED-5 (Akanbi et al., 2003, Olaniran and Abiose, 2018). The smooth paste divided to 8 portions ( $800 \mathrm{~g}$ each); Fermented paste without biopreservative served as control and labeled PWB. The garlic and ginger powder added to the slurry in different concentrations ( 2 and $4 \%)$. Other portions labeled as follows: $\mathrm{BPG}_{1}(2 \%$ garlic), $\mathrm{BPG}_{2}$ (4\% garlic); $\mathrm{BPG}_{3}$ ( $2 \%$ ginger), $\mathrm{BPG}_{4}\left(4 \%\right.$ ginger), $\mathrm{BPG}_{5}(2 \%$ garlic with $2 \%$ ginger), $\mathrm{BPG}_{6}\left(2 \%\right.$ garlic with $4 \%$ ginger), and $\mathrm{BPG}_{7}(4 \%$ garlic with $2 \%$ ginger). The mixtures were steadily homogenized in containers with a glass rod and fermented at ambient temperature $\left(27 \pm 2^{\circ} \mathrm{C}\right)$ for $24 \mathrm{~h}$. It was decanted and packaged in plastic containers stored at ambient temperature $(27 \pm$ $\left.2{ }^{\circ} \mathrm{C}\right)$ and refrigeration $\left(4 \pm 1{ }^{\circ} \mathrm{C}\right)$ temperatures. Samples were selected at random in 4 weeks in replicates for futher studies 


\section{Microbial Analyses}

\section{Enumeration of Microbes}

Enumeration of microbes by serial dilution of fermented paste was carried out during storage. Mixing of the paste $(5 \mathrm{~g})$ with $45 \mathrm{ml}$ of maximum recovery diluents (MRD) resulting in $10^{-1}$ dilution. The stock was further diluted till a preferred dilution was obtained. From each dilution, $1 \mathrm{ml}$ was pipetted into sterile petri dish prior to adding $20 \mathrm{~mL}$ each of molten Nutrient agar (NA) for enumeration microorganisms. Molten agar of de Man Rogosa-Sharpe (MRS) was added for Lactic acid bacteria (LAB) count and Potato dextrose agar (PDA) for yeast and mold count (to inhibit bacterial growth, $0.5 \mathrm{ml}$ of $3 \mathrm{mg} / \mathrm{ml}$ Streptomycin was incorporated). Petri dish in triplicates were incubated at $37^{\circ} \mathrm{C}$ for $24 \mathrm{~h}$ for the total viable count (TVC) and LAB count while for yeast and mold count media were incubated at $28 \pm 2^{\circ} \mathrm{C}$ for $72 \mathrm{~h}$. The microbial load in paste as storage progressed was determined to compute distinct colonies using a colony counter. Incubated Petri dish with 25-250 colonies was counted and numbers of colonies multiplied with reciprocal dilution factor (Harrigan, 1998; APHA, 2015)

\section{Characterization and Identification of Isolates}

Distinct colonies were streaked on solidified agar repeatedly to obtain pure isolate and subjected to microscopic examination for identification. The isolates were identified based on cultural, morphological characteristics and biochemica assays according to Taubeneck (2007), Wood, and Holzapfel (1995). Shape and elevation of the colonies were examined, Gram reaction, cell morphology and cell arrangement of the isolates were observed under a microscope. Identification of yeast and bacteria was done using conventional method carrying out catalase test, oxidase test, Gram staining, sugar fermentation and production of carbon dioxide. Relevant scheme were consulted (Harrigan, 1998; Stöckheim, 2007; Taubeneck, 2007; Wood and Holzapfel, 1995) for the identification of isolates strain.

\section{Determination of Titratable acidity and $\mathrm{pH}$}

The total titratable acidity (TTA) of fermented paste was done using $25 \mathrm{ml}$ of the slurry and 3 drops of phenolphthalein as indicator and titrated against $0.1 \mathrm{~N}$ Sodium hydroxide $(\mathrm{NaOH})$ to achieve pink color. The acidity of paste was calculated as lactic acid with conversion factor 0.09. $\mathrm{pH}$ meter (Corning Scholar 425, UL Laboratories, Shenzhen, China) was used for determination of $\mathrm{pH}$ values. Buffer 4.0 and 7.0 used to calibrate the $\mathrm{pH}$ meter and the electrode probes sanitized by swabbing with $90 \%$ ethanol before dipping in paste (AOAC 2010)

Preparation of extracts for total free amino acid, total reducing sugars, total soluble sugars and individual sugars assay

Extraction of the paste was carried out according to Omafuvbe (2006). Paste $(5 \mathrm{~g})$ was weighed into $250 \mathrm{ml}$ conical flask and $50 \mathrm{ml}$ of $80 \%$ ethanol (v/v) was added. The suspension was mixed and $10 \mathrm{ml}$ of petroleum ether was added to extract the fat in paste. The ethanol- petroleum ether was stirred using magnetic stirrer at room temperature for $30 \mathrm{~min}$ and centrifuged at $5000 \mathrm{rpm}$ for 30 minutes. The petroleum ether phase was discarded and clear ethanolic phase was collected and used for further analysis.

\section{Determination of total free amino acid}

Ninhydrin colorimetric method according to Omafuvbe (2006) to $1 \mathrm{ml}$ of the extract in labeled test tube, $0.5 \mathrm{ml}$ of cyanide acetate buffer $(\mathrm{pH} \mathrm{5.4)}$ ) and $0.5 \mathrm{~m}$ of $3.0 \%$ Ninhydrin solution in 2-methoxyethanol were added. The tubes were heated in a water bath for $15 \mathrm{~min}, 10 \mathrm{ml}$ of isopropyl alcohol: water mixture $(1: 1)$ was rapidly added then cooled to room temperature. The Optical Density (O.D) of the solution was read at $570 \mathrm{~nm}$ in a spectrophotometer (Model SP9, PyeUnican UK). The concentration of free amino acids in the extract was extrapolated from a standard curve of known concentrations of glycine.

\section{Determination of total reducing sugars}

The total reducing sugar content was determined using the dinitrosalicyclic acid (DNSA) reagent method described by Adepoju et al. (2016). One (1) milliliter of ethanolic extract was dispensed into test tubes and $2 \mathrm{ml}$ of DNSA was added. The mixture boiled for $5 \mathrm{~min}$, rapidly cooled under running water and $7 \mathrm{ml}$ of distilled water was added. The absorbance was read at $540 \mathrm{~nm}$ in a UV Spectrophotometer (Model SP9, PyeUnican UK) against reagent blank. Results were extrapolated from concentrations of a standard glucose calibration curve.

\section{Effect of Biopreservative on individual sugars in fermented paste}

Thin layer chromatography described by Adeniran and Abiose (2012) in the identification of individual sugars was used. Newly prepared standard sugars containing $0.5 \% \mathrm{w} / \mathrm{v}$ maltose, glucose, and galactose were stored in bottles Micropipette was used to spot the standard sugar solution on chromatogram sheet (pre-coated silica gel adsorbent for thin-layer chromatography) and the extracts. Prepared solvent system mixing $60 \%$ ethyl acetate, $15 \%$ glacier acetic acid, 15 $\%$ ethanol and $10 \%$ distilled water together. The dried spotted plate was immersed in the saturated chromatography tank containing the solvent system, uprightly positioned and allowed to develop for $1 \mathrm{~h}$. The developed sheet was gently removed and dried at room temperature. The detection reagent prepared by mixing naphthol resorcinol $(20 \mathrm{mg}), 90 \%$ ethanol $(10 \mathrm{ml})$, and concentrated sulphuric acid $(0.2 \mathrm{ml})$. Detection reagent was sprayed on the dried plate, dried in the oven at $100^{\circ} \mathrm{C}$ for 10 min resulting in defined and distinct spots on dried chromatogram sheet.

\section{RESULTS AND DISCUSSION}

\section{Effects of addition of biopreservative on fermented paste}

The total viable counts (TVC) of PWB (paste without preservative) increased ranging from 11.98-16.97 CFU/g (maize) and 11.99-15.99 CFU/g (sorghum) during storage (Table 1). The viable counts of $\mathrm{BPG}_{1}$ (bipreserved paste with $2 \%$ garlic) and $\mathrm{BPG}_{2}(4 \%$ garlic) gradually increased from $8.45-9.81 \mathrm{CFU} / \mathrm{g}$ and 8.35 to $11.59 \mathrm{CFU} / \mathrm{g}$ respectively in 4 weeks at ambient shelf life. The viable counts recorded in all biopreserved pastes in week 4 were lower than counts in week 2 compared to that of PWP (control) at week 2. The preservative effect in $\mathrm{BPG}_{1}$ in week $4(11.68 \mathrm{CFU} / \mathrm{g})$ was comparable to that of $\mathrm{BPG}_{3}$ in week $2(11.71 \mathrm{CFU} / \mathrm{g})$ in pastes produced from maize at ambient temperature as documented in table 1. Both $\mathrm{BPG}_{2}(11.59 \mathrm{CFU} / \mathrm{g})$ and $\mathrm{BPG}_{5}(11.40 \mathrm{CFU} / \mathrm{g})$ showed the nearly equivalent preservative effect in week 4 . The use of garlic- ginger in combination with refrigeration further reduced total viable counts of preserved paste during the 4 weeks of storage by extending the shelf life of the paste by $200 \%$. Also, TVC of $\mathrm{BPG}_{7}$ was stable at refrigeration temperature during storage. The lowest TVC count $\left(1.27 \mathrm{CFU} / \mathrm{g}\right.$ ) was recorded during storage in $\mathrm{BPG}_{7}$ (preserved paste with $4 \%$ garlic- $2 \%$ ginger) which was prepared from maize (supplementary 1 ).

Table 1 Total Viable Count (CFU/g) of biopreserved fermented pastes at ambient temperature

\begin{tabular}{|c|c|c|c|c|c|c|c|c|}
\hline $\begin{array}{l}\text { Time } \\
\text { (weeks) }\end{array}$ & PWB & $\mathrm{BPG}_{1}$ & $\mathrm{BPG}_{2}$ & $\mathrm{BPG}_{3}$ & $\mathrm{BPG}_{4}$ & $\mathrm{BPG}_{5}$ & $\mathrm{BPG}_{6}$ & $\mathrm{BPG}_{7}$ \\
\hline \multicolumn{9}{|l|}{ Maize } \\
\hline 0 & $11.98 \pm 0.11^{\mathrm{a}}$ & $8.45 \pm 0.10^{c}$ & $8.35 \pm 0.13^{c}$ & $8.65 \pm 0.14^{\mathrm{c}}$ & $8.62 \pm 0.10^{c}$ & $8.90 \pm 0.10^{b}$ & $8.91 \pm 0.10^{b}$ & $8.29 \pm 0.10^{\mathrm{d}}$ \\
\hline 4 & $16.97 \pm 0.10^{\mathrm{a}}$ & $11.68 \pm 0.15^{\mathrm{b}}$ & $11.59 \pm 0.13^{\mathrm{d}}$ & $11.89 \pm 0.10^{\mathrm{c}}$ & $11.71 \pm 0.15^{\mathrm{b}}$ & $11.40 \pm 0.15^{\mathrm{b}}$ & $11.34 \pm 0.12^{\mathrm{b}}$ & $11.30 \pm 0.15^{\mathrm{b}}$ \\
\hline \multicolumn{9}{|l|}{ Sorghum } \\
\hline 0 & $11.99 \pm 0.15^{\mathrm{a}}$ & $11.63 \pm 0.10^{\mathrm{c}}$ & $11.57 \pm 0.10^{\mathrm{c}}$ & $11.76 \pm 0.12^{b}$ & $11.65 \pm 0.10^{\mathrm{c}}$ & $11.43 \pm 0.10^{\mathrm{d}}$ & $11.34 \pm 0.15^{\mathrm{c}}$ & $11.45 \pm 0.11^{\mathrm{d}}$ \\
\hline
\end{tabular}

Means followed by different superscripts are significantly different across rows (p < 0.05). Keys: PWB (paste without biopreservative), $\mathrm{BPG}_{1}\left(2 \%\right.$ garlic), $\mathrm{BPG}_{2}$ (4\% garlic) $\mathrm{BPG}_{3}\left(2 \%\right.$ ginger), $\mathrm{BPG}_{4}(4 \%$ ginger $), \mathrm{BPG}_{5}(2 \%$ garlic- $2 \%$ ginger $), \mathrm{BPG}_{6}(2 \%$ garlic $-4 \%$ ginger $)$, and $\mathrm{BPG}_{7}(4 \%$ garlic- $2 \%$ ginger).

Lactic acid bacteria counts for all samples during storage for 4 weeks ranged from 8.30 to $16.96 \mathrm{CFU} / \mathrm{g}$ (maize) and $8.40-13.93 \mathrm{CFU} / \mathrm{g}$ (sorghum) at ambient temperature. LAB counts of biopreserved paste increased all through the 4 weeks of storage (Table 2). The LAB counts of PWP (13.82 CFU/g), BPG
(13.77 CFU/g) and $\mathrm{BPG}_{4}(13.80 \mathrm{CFU} / \mathrm{g})$ observed in fermented paste produced using sorghum; at ambient temperature showed no significant difference at the end of week 4. Also, the use of only garlic and garlic-ginger showed stabilizing effect on lactic acid bacteria growth in 4 weeks. The significant distinction in 
LAB counts of garlic-ginger as biopreservatives as the storage of paste progressed was noticeable. This demonstrated more antimicrobial activity of garlic against gram-positive bacteria and gram-negative bacteria.

Yeast and mould counts in PWP ranged from 8.81-13.76 CFU/g (maize) and 8.39-15.68 CFU/g (sorghum). Addition of garlic and garlic-ginger as biopreservatives significantly reduced yeast and mould counts in 4 weeks at ambient temperature from 13.76 and $15.68 \mathrm{CFU} / \mathrm{g}$ to range of $9.45-11.59 \mathrm{CFU} / \mathrm{g}$ and 11.39-13.92 CFU/g in pastes produced form maize and sorghum respectively. Yeast and mould counts in $\mathrm{BPG}_{6}$ were relatively constant (4.86-4.95 and 5.91-5.99 $\mathrm{CFU} / \mathrm{g}$ ) in paste from maize and sorghum at refrigeration temperature (Table 3). Garlic was found to be more effective than ginger against yeast and mould count during storage. Ajoene, a garlic-derived sulfur-containing compound reported by Olaniran et al. (2020) to be responsible for this observation. Low $\mathrm{LAB}$ and yeast count in preserved pastes at both temperatures may be due to the antimicrobial properties of garlic and ginger (Asimi et al., 2017). Similar reports by Oladipo and Jadesimi, (2013) and Olaniran et al. (2015) during the storage of food products preserved singly with either ginger or garlic was documented. $\mathrm{BPG}_{6}(4 \%$ garlic- $2 \%$ ginger) had the best effect on the total viable, Lactic acid bacteria and yeast count during storage of paste produced from maize and sorghum.

Table 2 Lactic Acid Bacteria Count (CFU/g) of biopreserved fermented pastes at ambient temperature

\begin{tabular}{|c|c|c|c|c|c|c|c|c|}
\hline $\begin{array}{l}\begin{array}{l}\text { Time } \\
\text { (weeks) }\end{array} \\
\end{array}$ & PWB & $\mathrm{BPG}_{1}$ & $\mathrm{BPG}_{2}$ & $\mathrm{BPG}_{3}$ & $\mathrm{BPG}_{4}$ & $\mathrm{BPG}_{5}$ & $\mathrm{BPG}_{6}$ & $\mathrm{BPG}_{7}$ \\
\hline \multicolumn{9}{|l|}{ Maize } \\
\hline 0 & $9.34 \pm 0.15^{\mathrm{bc}}$ & $8.76 \pm 0.10^{b}$ & $9.43 \pm 0.01^{\mathrm{b}}$ & $9.13 \pm 0.11^{\mathrm{c}}$ & $9.63 \pm 0.15^{\mathrm{a}}$ & $8.90 \pm 0.10^{\mathrm{d}}$ & $8.46 \pm 0.03^{\mathrm{e}}$ & $8.30 \pm 0.02^{f}$ \\
\hline 2 & $13.92 \pm 0.10^{\mathrm{a}}$ & $9.70 \pm 0.15^{\mathrm{d}}$ & $9.17 \pm 0.12^{\mathrm{f}}$ & $11.60 \pm 0.05^{\mathrm{b}}$ & $9.99 \pm 0.01^{\mathrm{c}}$ & $9.34 \pm 0.02^{\mathrm{e}}$ & $9.03 \pm 0.05^{\mathrm{g}}$ & $9.01 \pm 0.03^{\mathrm{g}}$ \\
\hline 4 & $16.96 \pm 0.02^{\mathrm{a}}$ & $9.94 \pm 0.04^{\mathrm{d}}$ & $9.80 \pm 0.03^{\mathrm{c}}$ & $11.95 \pm 0.01^{\mathrm{b}}$ & $11.45 \pm 0.03^{\mathrm{c}}$ & $9.74 \pm 0.01^{\mathrm{e}}$ & $9.62 \pm 0.06^{\mathrm{f}}$ & $9.70 \pm 0.01^{\mathrm{e}}$ \\
\hline \multicolumn{9}{|c|}{ Sorghum } \\
\hline 0 & $11.60 \pm 0.11^{\mathrm{a}}$ & $9.43 \pm 0.12^{\mathrm{ab}}$ & $8.51 \pm 0.15^{\mathrm{d}}$ & $9.91 \pm 0.10^{\mathrm{b}}$ & $9.82 \pm 0.10^{\mathrm{b}}$ & $8.64 \pm 0.11^{\mathrm{c}}$ & $8.40 \pm 0.15^{\mathrm{e}}$ & $8.48 \pm 0.15^{\mathrm{f}}$ \\
\hline 2 & $13.93 \pm 0.10^{\mathrm{a}}$ & $11.68 \pm 0.13^{\mathrm{c}}$ & $11.63 \pm 0.01^{\mathrm{c}}$ & $11.80 \pm 0.03^{b}$ & $11.89 \pm 0.05^{\mathrm{b}}$ & $10.73 \pm 0.05^{\mathrm{e}}$ & $10.45 \pm 0.01^{\mathrm{e}}$ & $10.69 \pm 0.05^{\mathrm{d}}$ \\
\hline 4 & $13.82 \pm 0.05^{\mathrm{a}}$ & $11.86 \pm 0.03^{b}$ & $11.76 \pm 0.05^{\mathrm{c}}$ & $13.77 \pm 0.05^{\mathrm{a}}$ & $13.80 \pm 0.01^{\mathrm{a}}$ & $11.71 \pm 0.08^{\mathrm{c}}$ & $11.58 \pm 0.02^{\mathrm{d}}$ & $11.67 \pm 0.00^{\mathrm{d}}$ \\
\hline
\end{tabular}

Means followed by different superscripts are significantly different across rows ( $<<0.05$ ). Keys: PWB (paste without biopreservative), BPG ( $2 \%$ garlic), $\mathrm{BPG}_{2}$ (4\% garlic); $\mathrm{BPG}_{3}$ (2\% ginger), $\mathrm{BPG}_{4}$ (4\% ginger), $\mathrm{BPG}_{5}$ ( $2 \%$ garlic- $2 \%$ ginger), $\mathrm{BPG}_{6}\left(2 \%\right.$ garlic- $4 \%$ ginger), and $\mathrm{BPG}_{7}(4 \%$ garlic- $2 \%$ ginger).

Table 3 Yeast count (CFU/g) of biopreserved fermented pastes at ambient temperature

\begin{tabular}{ccccccccc}
\hline $\begin{array}{l}\text { Time } \\
\text { (weeks) }\end{array}$ & PWB & $\mathrm{BPG}_{1}$ & $\mathrm{BPG}_{2}$ & $\mathrm{BPG}_{3}$ & $\mathrm{BPG}_{4}$ & $\mathrm{BPG}_{5}$ & $\mathrm{BPG}_{6}$ & $\mathrm{BPG}_{7}$ \\
\hline Maize & & & & & & & \\
\hline 0 & $8.81 \pm 0.03^{\mathrm{a}}$ & $5.36 \pm 0.01^{\mathrm{d}}$ & $5.27 \pm 0.00^{\mathrm{c}}$ & $6.63 \pm 0.02^{\mathrm{b}}$ & $5.78 \pm 0.01^{\mathrm{b}}$ & $4.74 \pm 0.04^{\mathrm{d}}$ & $4.86 \pm 0.03^{\mathrm{d}}$ & $4.69 \pm 0.00^{\mathrm{d}}$ \\
2 & $11.60 \pm 0.03^{\mathrm{a}}$ & $8.74 \pm 0.03^{\mathrm{c}}$ & $8.56 \pm 0.03^{\mathrm{c}}$ & $9.86 \pm 0.03^{\mathrm{b}}$ & $9.60 \pm 0.03^{\mathrm{b}}$ & $8.45 \pm 0.03^{\mathrm{d}}$ & $8.40 \pm 0.03^{\mathrm{d}}$ & $8.30 \pm 0.03^{\mathrm{e}}$ \\
4 & $13.76 \pm 0.03^{\mathrm{a}}$ & $9.86 \pm 0.03^{\mathrm{c}}$ & $9.81 \pm 0.03^{\mathrm{c}}$ & $11.53 \pm 0.03^{\mathrm{b}}$ & $11.39 \pm 0.03^{\mathrm{b}}$ & $9.72 \pm 0.03^{\mathrm{e}}$ & $9.57 \pm 0.03^{\mathrm{d}}$ & $9.45 \pm 0.03^{\mathrm{d}}$ \\
& & & & & & & & \\
Sorghum & & & & & & & & \\
\hline 0 & $8.39 \pm 0.01^{\mathrm{a}}$ & $6.67 \pm 0.02^{\mathrm{b}}$ & $6.48 \pm 0.01^{\mathrm{b}}$ & $6.61 \pm 0.05^{\mathrm{b}}$ & $6.73 \pm 0.03^{\mathrm{b}}$ & $6.32 \pm 0.00^{\mathrm{c}}$ & $5.91 \pm 0.08^{\mathrm{c}}$ & $5.98 \pm 0.05^{\mathrm{c}}$ \\
2 & $11.87 \pm 0.03^{\mathrm{a}}$ & $8.85 \pm 0.03^{\mathrm{c}}$ & $8.81 \pm 0.03^{\mathrm{c}}$ & $9.94 \pm 0.03^{\mathrm{b}}$ & $9.91 \pm 0.03^{\mathrm{b}}$ & $8.83 \pm 0.03^{\mathrm{c}}$ & $8.36 \pm 0.03^{\mathrm{d}}$ & $8.74 \pm 0.03^{\mathrm{c}}$ \\
4 & $15.68 \pm 0.03^{\mathrm{a}}$ & $11.93 \pm 0.03^{\mathrm{c}}$ & $11.73 \pm 0.03^{\mathrm{c}}$ & $13.92 \pm 0.03^{\mathrm{b}}$ & $13.85 \pm 0.03^{\mathrm{b}}$ & $11.67 \pm 0.03^{\mathrm{c}}$ & $11.39 \pm 0.03^{\mathrm{d}}$ & $11.50 \pm 0.03^{\mathrm{d}}$ \\
\hline
\end{tabular}

Means followed by different superscripts are significantly different across rows (p < 0.05). Keys: PWB (paste without bio-preservative), $\mathrm{BPG}_{1}\left(2 \%\right.$ garlic), $\mathrm{BPG}_{2}$ (4\% garlic); $\mathrm{BPG}_{3}(2 \%$ ginger $), \mathrm{BPG}_{4}(4 \%$ ginger $), \mathrm{BPG}_{5}(2 \%$ garlic- $2 \%$ ginger $), \mathrm{BPG}_{6}(2 \%$ garlic $-4 \%$ ginger $)$, and $\mathrm{BPG}_{7}(4 \%$ garlic- $2 \%$ ginger $)$.

Identification and occurrence pattern of microorganisms in fermented paste

Eight lactic acid bacteria isolates were identified as Lactobacillus plantarum, Lactobacillus amylovorus, Leuconostoc mensenteroides, Lactobacillus delbrueckii, Lactobacillus brevis, Lactobacillus fermentum, Pediococcus pentosaceus, and Pediococcus acidilactici. Lactobacillus plantarum was dominant throughout the period of storage at ambient and refrigeration temperature in paste produced from sorghum. Lactobacillus amylovorus was present for first 2 weeks at ambient temperature and throughout at refrigeration temperature. Leuconostoc mensenteroides was also present throughout storage at refrigeration temperature but only in the first week at ambient temperature. Lactobacillus brevis, Pediococcus pentosaceus, and Pediococcus acidilactic isolated in week 2 at both temperatures as presented in Table 4 . They have been reported as major lactic acid bacteria isolated from fermented cereal dough (Adesulu-Dahunsi et al., 2017; Bello et al., 2018; Okoronkwo, 2014; Olayiwola et al., 2017; Wakil and Ajayi, 2013). Yeast isolates were identified as Saccharomyces cerevisiae, Saccharomyces rouxii, Candida utilis, Candida mycoderma, Candida tropicalis, Candida krusei, Hansenula anomala, and Rhodotorula glutinis (Table 5). Saccharomyces cerevisiae and Saccharomyces rouxii were dominant for 4 weeks as shown in the occurrence pattern of yeas isolates. The growth of Candida utilis, Candida mycoderma, Candida tropicalis,
Candida krusei, and Rhodotorula glutinis were inhibited during storage in pastes having garlic. Garlic has been reported to have high anti-candida activity and fungicidal effects against Rhodotorula (Ali and Mustafa, 2009; Ogunsakin et al., 2015).

\section{Total Titratable Acidity and pH of paste}

The total titratable acidity (TTA) value of the pastes increased at ambient and refrigeration temperatures during the 4 weeks of storage respectively. Control sample from paste produced from sorghum had the highest titratable acidity (0.25) while lowest was observed in $\mathrm{BPG}_{7}(0.15)$ in week 4 at ambient temperature. The TTA and $\mathrm{pH}$ of $\mathrm{BPG}_{6}$ and $\mathrm{BPG}_{7}$ were stable during storage (figures 1 and 2). $\mathrm{BPG}_{7}$ total titratable acidity and $\mathrm{pH}$ were stable at refrigeration temperature. The variations in acid tolerance of microorganisms could be attributed to their relative ATPase activities as the $\mathrm{pH}$ decreases (Wakil and Ajayi, 2013). Effective inhibition of microorganisms depends on numbers of lactic acid bacteria sufficient to decrease the $\mathrm{pH}$ rapidly to levels that inhibit growth of pathogen. Decreased in $\mathrm{pH}$ and increase in TTA in the study was in agreement with Oyedeji et al. (2013).

Table 4 Morphological and Biochemical Characteristics of Bacteria Isolates from of biopreserved fermented pastes

\begin{tabular}{|c|c|c|c|c|c|c|c|c|c|c|}
\hline \multirow[t]{2}{*}{ Test } & \multirow[b]{2}{*}{1} & \multicolumn{9}{|c|}{ Isolates } \\
\hline & & 2 & 3 & 4 & 5 & 6 & 7 & 8 & 9 & 10 \\
\hline Morphology & Rod & $\begin{array}{c}\text { Cocc } \\
\text { i }\end{array}$ & Rod & Rod & Cocci & Rod & Rod & Cocci & Cocci & Rod \\
\hline Colour of growth & Cream & $\begin{array}{l}\text { Yell } \\
\text { ow }\end{array}$ & Cream & Cream & Cream & Cream & Cream & Cream & Cream & Cream \\
\hline Gram reaction & + & + & + & + & + & + & + & + & + & + \\
\hline $\begin{array}{l}\text { Catalase test } \\
\text { Growth at: }\end{array}$ & + & + & - & - & - & - & - & - & - & - \\
\hline $15^{\circ} \mathrm{C}$ & - & + & + & - & + & - & + & + & + & - \\
\hline $45^{\circ} \mathrm{C}$ & + & + & - & + & - & + & - & - & + & + \\
\hline Production of $\mathrm{CO}_{2}$ & + & $\mathrm{Nd}$ & - & - & + & - & + & - & - & - \\
\hline Starch & + & - & - & + & - & - & - & - & - & - \\
\hline Nitrate & - & - & - & - & - & - & + & $\mathrm{Nd}$ & $\mathrm{Nd}$ & + \\
\hline Dextran production & + & + & - & - & + & - & - & - & - & - \\
\hline
\end{tabular}




\begin{tabular}{|c|c|c|c|c|c|c|c|c|c|c|}
\hline $\begin{array}{l}\mathrm{NH}_{3} \text { from arginine } \\
\text { fermentation of: }\end{array}$ & - & + & - & - & $\mathrm{Nd}$ & - & + & + & - & + \\
\hline Glucose & + & + & - & - & + & + & + & + & + & + \\
\hline Lactose & + & - & + & - & + & + & + & + & + & + \\
\hline Maltose & + & & & + & + & + & + & + & + & + \\
\hline Arabinose & - & - & + & + & + & - & + & - & + & + \\
\hline Trehalose & + & - & + & + & + & + & - & + & + & + \\
\hline Salicin & - & - & + & + & + & - & - & + & + & - \\
\hline Sucrose & + & + & + & - & + & + & + & - & - & + \\
\hline Raffinose & - & - & + & - & + & - & + & + & + & + \\
\hline Mannitol & + & + & $\mathrm{Nd}$ & - & + & - & - & + & + & $\mathrm{Nd}$ \\
\hline Xylose & - & + & + & - & + & - & + & - & + & + \\
\hline Fructose & + & + & $\mathrm{Nd}$ & - & + & $\mathrm{Nd}$ & & + & + & \\
\hline Galactose & + & + & + & + & + & - & + & + & + & + \\
\hline Citrate & - & + & & & + & & & & & \\
\hline $\begin{array}{l}\text { Probable identity of } \\
\text { the organism }\end{array}$ & $\begin{array}{c}\text { Corynebacterium } \\
\text { spp. }\end{array}$ & $\begin{array}{c}\text { M. } \\
\text { luteus }\end{array}$ & L. plantarum & $\begin{array}{c}L . \\
\text { amylovorus }\end{array}$ & $\begin{array}{c}L . \\
\text { mensenteroides }\end{array}$ & $\begin{array}{c}\text { L. } \\
\text { delbrueckii }\end{array}$ & L. brevis & $\begin{array}{c}P . \\
\text { pentosaceus }\end{array}$ & $\begin{array}{c}P . \\
\text { acidilactici }\end{array}$ & $\begin{array}{c}L . \\
\text { fermentum }\end{array}$ \\
\hline
\end{tabular}

Table 5 Morphological and Biochemical Characteristics of Yeast Isolates from of biopreserved fermented pastes

\begin{tabular}{|c|c|c|c|c|c|c|c|c|}
\hline Test & & & & Isolates & & & & \\
\hline & 1 & 2 & 3 & 4 & 5 & 6 & 7 & 8 \\
\hline $\begin{array}{l}\text { Morphology: } \\
\text { Colour }\end{array}$ & Cream & Cream & Red & Cream & Cream & Yellow & Cream & \\
\hline Shape & Ovoid & Ovoid & Ovoid & Spherical & Ovoid & Cylindrical & Cylindrical & Cylindrical \\
\hline $\begin{array}{l}\text { Reproduction } \\
\text { (Budding) }\end{array}$ & Polar & $\begin{array}{c}\text { Polar } \\
\text { Budding }\end{array}$ & Multilateral & $\begin{array}{c}\text { Polar } \\
\text { Budding }\end{array}$ & Multilateral & $\begin{array}{l}\text { Multilateral } \\
\text { Budding }\end{array}$ & Multilateral & Multilateral \\
\hline \multicolumn{9}{|l|}{ Fermentation: } \\
\hline Glucose & + & + & - & + & + & + & + & - \\
\hline Sucrose & + & - & - & + & + & - & + & - \\
\hline Maltose & + & $+(\mathrm{w})$ & - & $+(w)$ & + & - & - & - \\
\hline Galactose & + & - & - & + & + & - & - & - \\
\hline Raffinose & + & - & - & $+(w)$ & - & - & + & - \\
\hline Lactose & - & - & - & - & - & - & - & - \\
\hline \multicolumn{9}{|l|}{ Sugar assimilation } \\
\hline Glucose & + & + & + & + & + & + & + & + \\
\hline Sucrose & + & - & + & + & + & - & + & - \\
\hline Maltose & + & + & + & + & + & - & + & - \\
\hline Galactose & + & + & + & + & + & - & - & - \\
\hline Raffinose & + & - & + & + & - & - & + & - \\
\hline Lactose & - & - & - & - & - & - & - & - \\
\hline Trehalose & - & - & + & + & - & - & - & - \\
\hline Pellicle & - & - & - & + & + & + & - & + \\
\hline Nitrate assimilation & - & - & - & + & - & - & + & - \\
\hline $\begin{array}{l}\text { Probable identity of } \\
\text { organism }\end{array}$ & $\begin{array}{c}\text { Saccharomyces } \\
\text { Cerevisiae }\end{array}$ & $\begin{array}{l}\text { Saccharomyces } \\
\text { Rouxii }\end{array}$ & $\begin{array}{l}\text { Rhodotorula } \\
\text { glutinis }\end{array}$ & $\begin{array}{c}\text { Hansenula } \\
\text { anomala }\end{array}$ & $\begin{array}{l}\text { Candida } \\
\text { tropicalis }\end{array}$ & Candida krusei & Candida utilis & Candida mycoderma \\
\hline
\end{tabular}

Key: -: negative; +: positive; w: weak
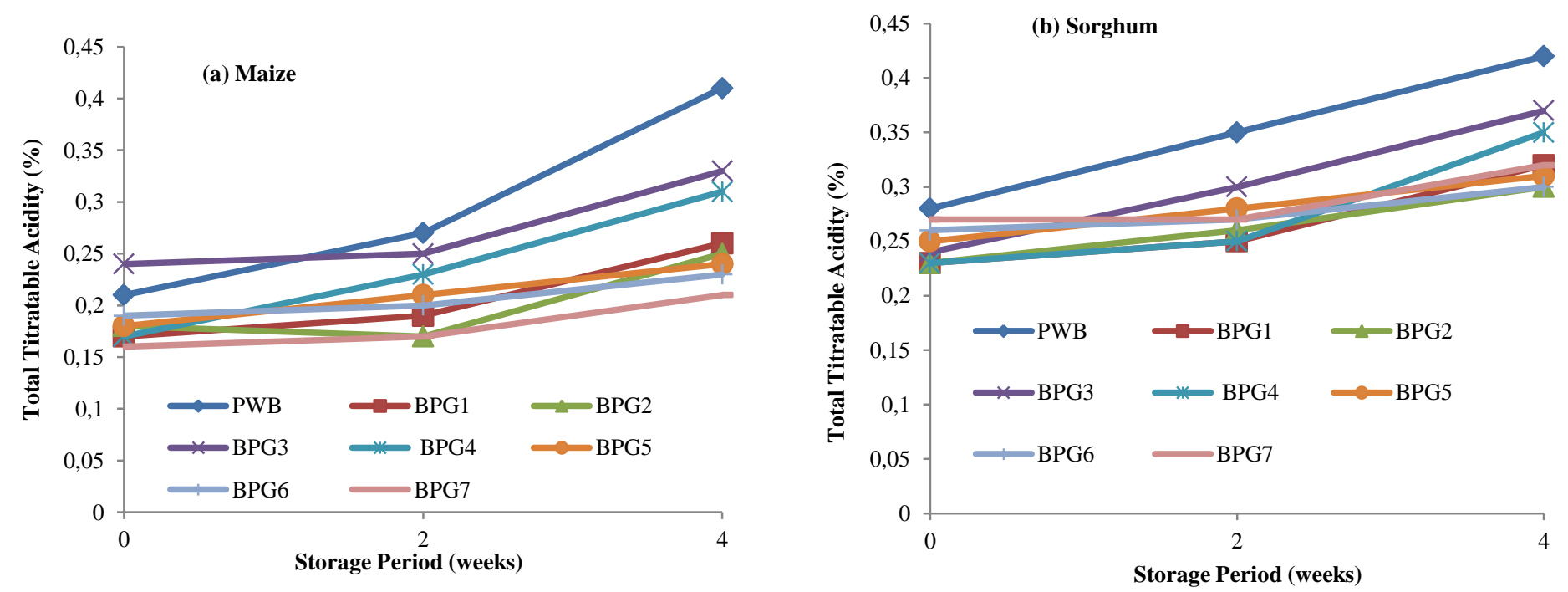

Figure 1 Total titratable acidity of Biopreserved fermented pastes at Ambient Temperature (a) maize, (b) Sorghum 

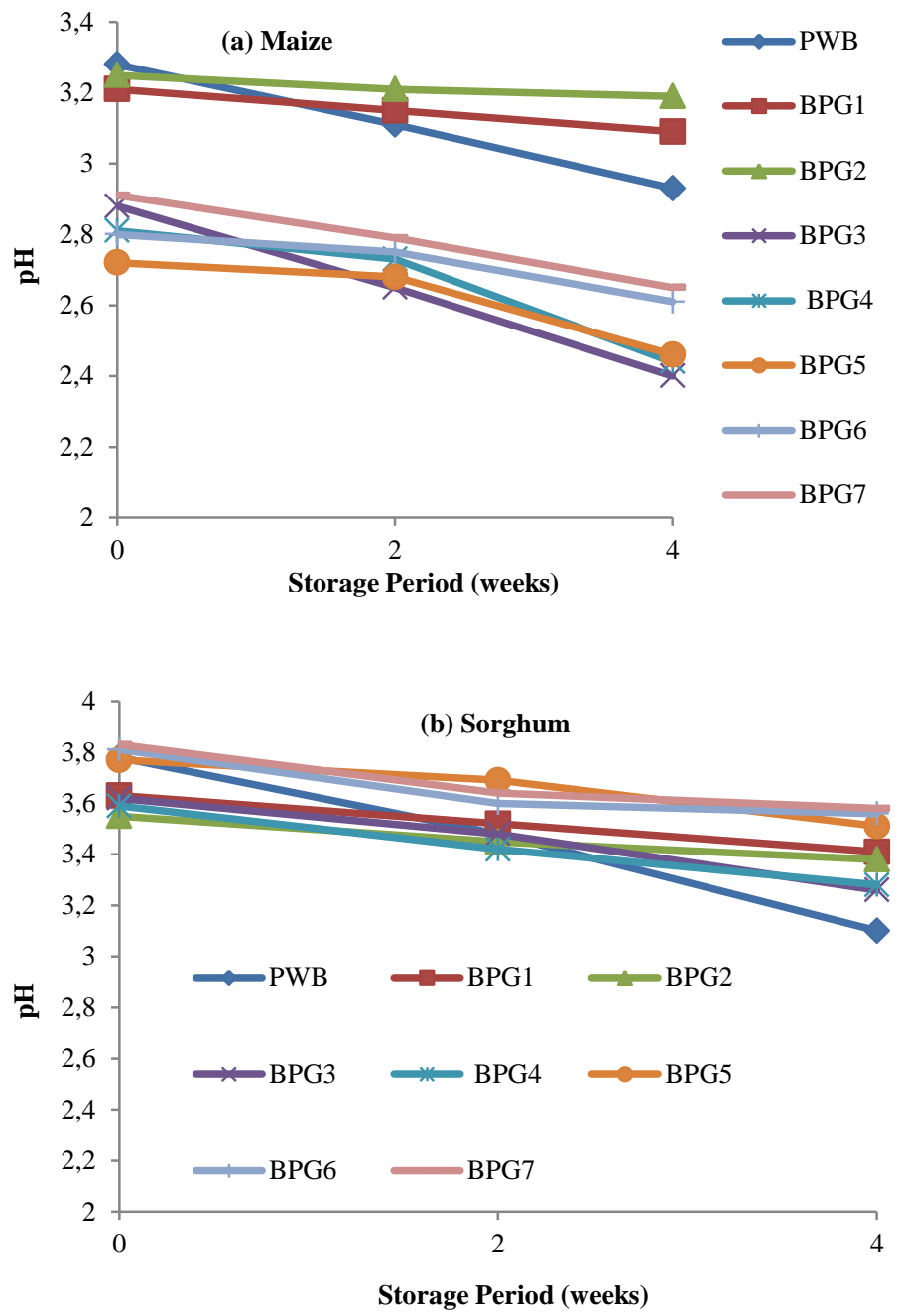

Figure $2 \mathrm{pH}$ of Biopreserved fermented pastes at Ambient Temperature (a) maize, (b) Sorghum

\section{The total free amino acid of fermented paste}

The total free amino acid (TFAA) content of pastes ranged from 44.96 to 73.70 $\mathrm{mg} / \mathrm{ml}$ and $37.18-102.56 \mathrm{mg} / \mathrm{ml}$ for pastes form maize and sorghum at ambient temperature respectively. Stable TFAA observed during storage of $\mathrm{BPG}_{1}, \mathrm{BPG}_{2}$ $\mathrm{BPG}_{4}, \mathrm{BPG}_{5}$ and $\mathrm{BPG}_{7}$ at ambient temperature (Figure 3). The TFAA content of PWB increased throughout the 4 weeks of storage at a refrigeration temperature from 44.69 to $50.62 \mathrm{mg} / \mathrm{ml}$ and 37.18 to $51.00 \mathrm{mg} / \mathrm{ml}$ in pastes form maize and sorghum respectively. Rojas-Molina et al. (2008) reported a similar observation of increased in free amino acid.
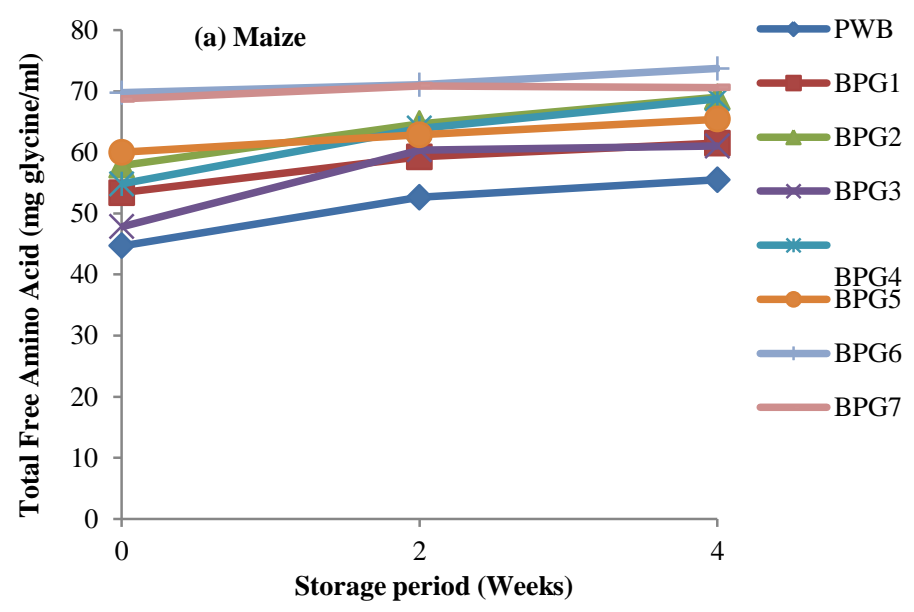

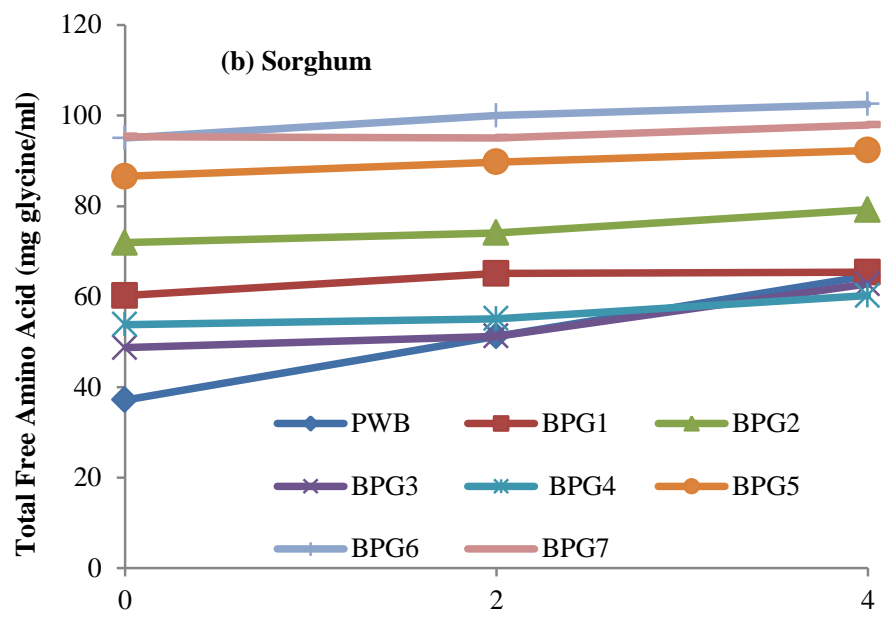

Figure 3 Total free amino acid of biopreserved fermented pastes at Ambient Temperature

\section{Total Reducing Sugar Content of fermented paste}

The total reducing sugar (TRS) of paste during storage ranged from 6.21 - 41.87 $\mathrm{mg} / \mathrm{ml}$ (maize) and 19.97-51.32 $\mathrm{mg} / \mathrm{ml}$ (sorghum) at ambient temperature. Relatively stable total reducing sugar content was documented in $\mathrm{BPG}_{4}$ and $\mathrm{BPG}_{5}$ (Figures 4). PWB (Control paste from maize) had the lowest total reducing sugar $(6.21 \mathrm{mg} / \mathrm{ml})$ in 4 weeks while $\mathrm{BPG}_{5}$ from sorghum had the highest $(51.32$ $\mathrm{mg} / \mathrm{ml}$ ) at ambient temperature. Increased total soluble sugar may be due to maximum breaking down of starch substrates to simpler sugars by amylolytic enzymes produced during fermentation (Adesulu et al. 2014; Okafor et al. 2018; Oyarekua and Adeyeye, 2009). Low reducing sugar content in fermented pastes has been reported as a good attribute because methods of preparing weaning foods involve heat processing by Oyerekau and Adeyeye (2009).
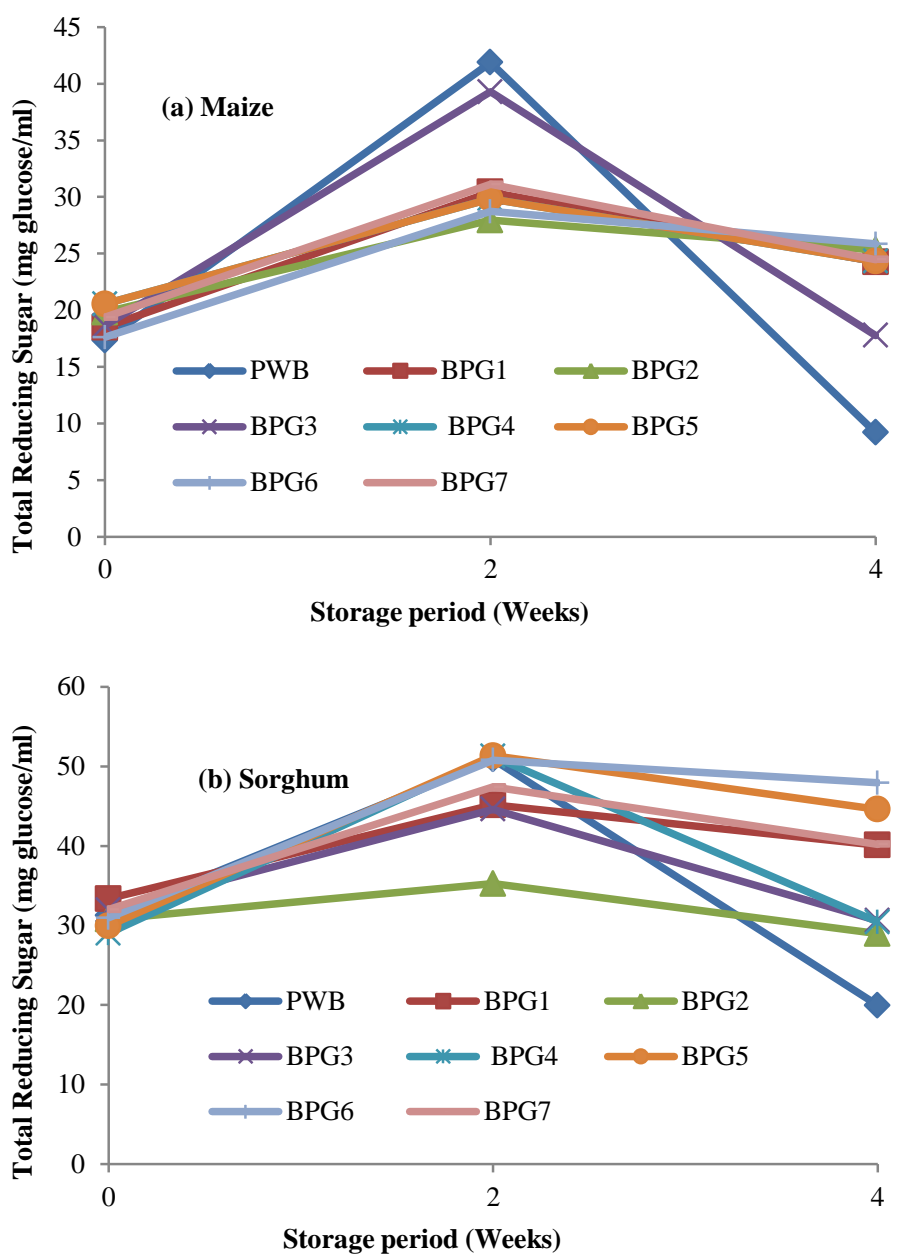

Figure 4 Total reducing sugar of biopreserved fermented pastes at Ambient Temperature 
Identification of individual sugars in fermented paste extract

Individual sugars were not present in all paste extracts at week 0 . However in paste produced from maize; glucose was the main sugar present in $\mathrm{PWB}, \mathrm{BPG}_{1}$, $\mathrm{BPG}_{2}$, and $\mathrm{BPG}_{4}, \mathrm{BPG}_{5}, \mathrm{BPG}_{6}$ and $\mathrm{BPG}_{7}$ at week 4 at ambient temperature. Also in pastes made from sorghum, sucrose and glucose with calculated refractive index ( $\mathrm{Rf}$ value) 0.31 and 0.41 were present in $\mathrm{BPG}_{6}$ in 4 weeks at ambient temperature. Fructose with calculated refractive index $\left(\mathrm{R}_{\mathrm{f}}\right.$ value) of 0.46 was identified in $\mathrm{BPG}_{3}, \mathrm{BPG}_{5}, \mathrm{BPG}_{6}$, and $\mathrm{BPG}_{7}$ in 4 weeks at ambient temperature. Individual sugars were not present in all paste extracts stored at refrigeration temperature. Glucose reported as one of the major monosaccharide present in significant quantity in cereal grains such as maize and sorghum by Omemu (2018) and Akinrinola et al. (2014).

\section{CONCLUSION}

This study established that fermented paste produced from maize and sorghum can be effectively biopreserved with garlic-ginger for 4 weeks at ambien temperature without deteriorating. The most effective combination was $4 \%$ garlic and $2 \%$ ginger in maize and sorghum as biopreservatives. Thus, garlic, ginger addition are highly recommended as biopreservatives in fermented paste for extending shelf life in our bid to sustain its availability in remote communities with inconsistent power supply and probable application for industria production.

Acknowledgments: Institute of Agricultural Research and Training (I.A.R.T.), Ibadan, Nigeria is appreciated for providing quality protein maize used for this research.

\section{REFERENCES}

Akinrinola, A. Adejimi M., Idabor, V., Oliseh, C., Sanni, R., Oshagbemi, H., Oyefuga, O. 2014. Dietary Fortification of Ogi (Maize slurry ) with Okra seed flour and its Nutritional value. Scholarly Journal of Agricultural Science, 4(4), 213-217. https://www.researchgate.net/publication/291335302

Adepoju, A. A., Abiose, S. H., Adeniran, H. A. 2016. Effect of pasteurization and selected chemical preservatives on Fura de nunu during storage. African Journal of Food Science and Technology, 7(8), 178-185. https://doi.org/10.14303/ajfst.2016.102

Adeniran, H. A., Abiose, S. H. 2012. Partial purification, characterization and hydrolytic activities of amylases from Bacillus licheniformis and Aspergillus niger cultured on agricultural residues. African Journal of Biotechnology, 11(6), 1465-1477. https://doi.org/10.5897/AJB10.2233

Adesulu-Dahunsi, A. T., Sanni, A. I., Jeyaram, K. 2017. Rapid differentiation among Lactobacillus, Pediococcus and Weissella species from some Nigerian indigenous fermented foods. https://doi.org/10.1016/j.lwt.2016.11.007

Adesulu, A., T., Awojobi, K., O. 2014. Enhancing sustainable development through indigenous fermented food products in Nigeria. African Journal of Microbiology Research, $\quad$ 8(12), 1338-1343. https://doi.org/10.5897/AJMR2013.5439

Akanbi, C. T., Ade-Omowaye, B. I., Ojo, A., Adeyemi, I. A. 2003. Effect of Processing Factors on Rheological Properties of Ogi. International Journal of Food Properties, 6(3), 405-418. https://doi.org/10.1081/JFP-120020118

Ali, A. A., Mustafa, M. M. 2009. Isolation, Characterization and Identification of Lactic Acid Bacteria from Fermented Sorghum Dough used in Sudanese Kisra Preparation. Pakistan Journal of Nutrition, 8(11), 1814-1818. http://citeseerx.ist.psu.edu/viewdoc/download?doi=10.1.1.604.1248\&rep=rep1\&t ype=pdf

AOAC. 2010. Official methods of analysis of AOAC International. Gaithersburg MD.: AOAC International. https://www.worldcat.org/title/official-methods-ofanalysis-of-aoac-international/oclc/649275444

APHA 2015. Compendium of Methods for the Microbiological Examination of Foods. Fifth edition, American Public Health Association Washington, DC., USA, p. 769-774.

Asimi, O. A., Sahu, N. P., Pal, A. K. 2013. Antioxidant activity and antimicrobial property of some Indian spices. International Journal of Scientific and Research Publications, 3(3). ww.ijsrp.org

Bello, O. O., Bello, T. K., Amoo, O. T., Atoyebi, Y. O. 2018. Comparative evaluation of microbiological and nutritional qualities of various cereal-based paps (Ogi) in Ondo State, Nigeria. International Journal of Environment, $\begin{array}{llll}\text { Agriculture } \quad \text { and } & \text { Botechnology, 676-685. }\end{array}$ https://doi.org/10.22161/ijeab/3.2.49

Gunaratna, N. S., Moges, D., Groote, H. De. 2019. Biofortified Maize Can Improve Quality Protein Intakes among Young Children in Southern Ethiopia. Nutrients, 11, 192. https://doi.org/10.3390/nu11010192

Harrigan, W. F. 1998. Laboratory methods in food microbiology. Academic Press.

Kulamarva, A. G., Sosle, V. R., Raghavan, G. S. V. 2009. Nutritional and Rheological Properties of Sorghum. International Journal of Food Properties,
12, 55-69. https://doi.org/10.1080/10942910802252148

Maseta, E., Mosha, T. C., Nyaruhucha, C., Laswai, H. 2017. Nutritional quality of quality protein maize-based supplementary foods. Nutrition and Food Science, 47(1), 42-52. https://doi.org/10.1108/NFS-04-2016-0042

Nath, S., Chowdhury, S., Dora, K., Sarkar, S. 2014. Role of Biopreservation in Improving Food Safety and Storage. Journal of Engineering Research and Applications www.Ijera.Com, 4(1), 26-32. www.ijera.com

Ogunsakin, O. A., Banwo, K., Ogunremi, O. R., Sanni, A. I. 2015 Microbiological and physicochemical properties of sourdough bread from sorghum flour. International Food Research Journal.

Okafor, U. I., Omemu, A. M., Obadina, A. O., Bankole, M. O., Adeyeye, S. A. O. 2018. Nutritional composition and antinutritional properties of maize ogi cofermented with pigeon pea. Food Science and Nutrition, 6(2), 424-439. https://doi.org/10.1002/fsn3.571

Okoronkwo, C. U. 2014. Isolation and Characterization of Lactic Acid Bacteria involved in the Fermentation of Millet and Sorghum sold in Nkwo-Achara market, Abia State.IOSR Journal of Environmental Science, Toxicology and Food Technology, www.iosrjournals.orgwww.iosrjournals.org42\%7C

Oladipo, I. C., Jadesimi, P. D. 2013. Microbiological Analysis and Nutritional Evaluation of West African soft cheese (wara) produced with different preservatives. American Journal of Food and Nutrition, 3(1), 13-21. https://doi.org/10.5251/ajfn.2013.3.1.13.21

Olaniran, A. F., Abiose, S. H. 2018. Proximate and antioxidant activities of biopreserved ogi flour with garlic and ginger. F1000Research, 7 (1936),1-13 https://doi.org/10.12688/f1000research.17059.1

Olaniran, A. F., Abiose, S. H. 2019. Nutritional evaluation of enhanced unsieved Ogi Paste with Garlic and Ginger. Preventive Nutrition and Food Science, 24(3), 348-356. https://doi.org/10.3746/pnf.2019.24.3.348

Olaniran, A. F., Abiose, S. H., Adeniran, A. H. 2015. Biopreservative Effect of Ginger (Zingiber officinale) and Garlic Powder (Allium sativum) on Tomato Paste. Journal of Food Safety, 35(4), 440-452. https://doi.org/10.1111/jfs.12193 Olaniran, A. F., Abiose, S. H., Gbadamosi, S. O. 2019. Nutritional Quality and Acceptability Evaluation of $O g i$ Flour Biofortified with Garlic and Ginger. Journal of Health Science, 7, 101-109. https://doi.org/10.17265/2328 7136/2019.02.005

Olaniran, A. F., Abu, H. E., Afolabi R. O. Okolie, C., Owolabi A., Akpor O. 2020. Comparative assessment of storage stability of Ginger-Garlic and Chemica preservation on Fruit juice blends. Potravinarstvo Slovak Journal of Food Sciences 14, 88-94. https://doi.org/10.5219/1262

Olayiwola, J. O., Inyang, V., Bello, M. A. 2017. Bacteriological and Proximate Evaluation of Ginger-Fortified Fermented Maize (OGI). American Journal of Food Technology, 12(6), 374-378. https://doi.org/10.3923/ajft.2017.374.378

Oluwakemi, A., Omodele, I. 2015. The current status of cereals (maize, rice and sorghum) crops cultivation in Africa: Need for integration of advances in transgenic for sustainable crop production. International Journal of Agricultural Policy and Research, https://doi.org/10.3923/ajft.2017.374.378

Omafuvbe, O. B. 2006. Effect of salt on the fermentation of soybean (Glycine max) into daddawa using Bacillus subtilis as starter culture. African Journal of Biotechnology , 5(10), 1001-1005. https://doi.org/10.5897/ajb06.169

Omemu, A. M. 2011. Fermentation dynamics during production of ogi, a Nigerian fermented cereal porridge. Report and Opinion, 3(4), 8-17. http://www.sciencepub.net/report

Omemu, A. M., Okafor, U. I., Obadina, A. O., Bankole, M. O., Adeyeye, S. A. O. 2018. Microbiological assessment of maize ogi cofermented with pigeon pea Food Science and Nutrition, 6(5), 1238- 1253. https://doi.org/10.1002/fsn3.651

Oyarekua, M. A., Adeyeye, E. I. 2009. Comparative Evaluation of the Nutritional Quality, Functional Properties and Amino Acid Profile of Co-Fermented Maize/Cowpea and Sorghum/Cowpea Ogi as Infant Complementary Food. Asian Journal of Clinical Nutrition, 1(1), 31-39. https://doi.org/10.3923/ajcn.2009.31.39

Oyedeji, O., Ogunbanwo, S. T., Onilude, A. A. 2013. Predominant Lactic Acid Bacteria Involved in the Traditional Fermentation of Fufu and Ogi, Two Nigerian Fermented Food Products. Food and Nutrition Sciences, 04(11), 40-46. https://doi.org/10.4236/fns.2013.411A006

Rojas-Molina, I., Gutiérrez, E., Cortés-Acevedo, M. E., Falcón, A., Bressani, R., Rojas, A., ... Rodríguez, M. E. (2008). Analysis of Quality Protein Changes in Nixtamalized QPM Flours as a Function of the Steeping Time. Cereal Chemistry Journal, 85(3), 409-416. https://doi.org/10.1094/CCHEM-85-3-0409

Singh, 2018. Recent approaches in food bio-preservation - a review. Open Veterinary Journal, 8(1), 104-111. doi: http://dx.doi.org/10.4314/ovj.v8i1.16

Stöckheim, A. 2007. J. Lodder (Editor), The Yeasts. A Taxonomic Study. II überarbeitete Auflage. X und 1385 S., 354 Abb. Amsterdam-London 1970: North Holland Publ. Co. \$ 65. Zeitschrift Für Allgemeine Mikrobiologie, 12(1), 82-82. https://doi.org/10.1002/jobm.19720120119

Tandzi, L. N., Mutengwa, C. S., Ngonkeu, E. L. M., Woïn, N., Vernon, G. (2017). Breeding for Quality Protein Maize ( QPM ) Varieties: A Review. Agronomy, 7, 80. https://doi.org/10.3390/agronomy7040080

Tattari, S., Kota, N., Technical Officer, S., Nimgulkar MPharm Scholar, C., 
Polasa, K., Panpatil, V. V, \& Nimgulkar, C. (2013). In vitro evaluation on antioxidant and antimicrobial activity of spice extracts of ginger, turmeric and garlic. $143 \sim$ Journal of Pharmacognosy and Phytochemistry, 2(3), 143-148. http://www.phytojournal.com/archives/2013/vol2issue3/PartC/39.1.pdf

Taubeneck, U. 2007. Gibbs B. M, Shapton D. A. (Editors), Identification Methods for Microbiologists. Part B (The Society of Applied Bacteriology, Technical Series No. 2). XI und 212 S., 55 Abb., 37 Tab. London-New York 1968: Academic Press 50 s. Zeitschrift Für Allgemeine Mikrobiologie, 10(3), 232-232. https://doi.org/10.1002/jobm.19700100315

Wakil, S., Ajayi, O. 2013. Production of lactic acid from Starchy-based food $\begin{array}{llll}\text { substrates. Journal of Applied Biosciences, } & 71(1), \quad 5673 .\end{array}$ https://doi.org/10.4314/jab.v71i1.9881

Wood, B. J. B., Holzapfel, W. H. (Editors). 1995. The Genera of Lactic Acid Bacteria. Boston, MA: Springer US. https://doi.org/10.1007/978-1-4615-5817-0 